\title{
Repercussões satíricas dos processos de escolarização do social nas ondas do rádio $(1930-1940)^{1}$
}

\author{
Maria Angela Borges Salvadori*
}

\begin{abstract}
Resumo
Este artigo analisa repercussões satíricas dos processos de es-

colarização do social no Brasil, presentes em antigos programas humorísticos de rádio, que, geralmente organizados pelo diálogo entre um professor e seus alunos, foram simultaneamente grandes sucessos em termos de audiência e alvos de uma crítica sistemática por parte daqueles que defendiam a radiodifusão como instrumento de divulgação da "verdadeira" cultura. Por meio do uso de fontes sonoras e impressas, objetiva compreender as razões do sucesso do gênero e, neste percurso, identificar as críticas à escola, à educação e seus sujeitos, que, jocosamente, veicularam, explicitadas em conflitos entre sonoras tradições populares e saberes escolares.
\end{abstract}

* Professora do Departamento de Filosofia da Educação e Ciências da Educação da Faculdade de Educação da Universidade de São Paulo (USP). mabsalvadori@usp.br

\section{Palavras-chave}

radiodifusão; humor; educação

1. Este artigo faz parte do projeto "Radiodifusão e educação no Brasil: repercussões satíricas dos processos de escolarização do social nos anos 1930-1940" e conta com apoio do Conselho Nacional de Desenvolvimento Científico e Tecnológico (CNPq Processo n. 401523/2010-1). 


\title{
Satirical repercussions of the social schooling processes in radio programs (1930-1940)
}

\begin{abstract}
This article analyzes satirical repercussions of the social schooling processes in Brazil found in old radio comedies which, usually built around the dialogue between a teacher and his or her students, were, on the one hand, huge audience successes and, on the other hand, subjected to systematic criticism from those who believed that radio broadcasting should be used as an instrument to disseminate the "true" culture. Through the use of sound and print records, the text seeks to understand the reasons behind the success of this genre and, in so doing, to identify the criticisms that these programs directed through humor at the school, at education and its agents, which were brought forward in conflicts between sonorous popular traditions and school knowledge.
\end{abstract}

Key words

radio broadcasting; humor; education. 


\section{Introdução}

Em maio de 2011, jornais da grande imprensa dedicaram espaço considerável às discussões sobre linguagem, motivados pela polêmica relativa ao livro Por uma vida melhor (Aguiar et al., 2009), destinado à educação de jovens e adultos. A obra, que participa do Programa Nacional de Livros Didáticos do Ministério da Educação, em um de seus capítulos, procura diferenciar a norma culta das variantes do falar popular e indica que há certos consentimentos na oralidade que desaparecem na escrita formal. A partir da divulgação de trechos do livro que, reproduzindo a fala cotidiana das ruas, continham "erros" gramaticais, quando comparados às regras da norma culta, o debate se polarizou entre aqueles que, de um lado, concebem a linguagem como socialmente construída e defendem a necessidade de a escola reconhecer a existência de uma diversidade de falas e falantes; de outro, os que possuem uma visão mais fechada tanto da linguagem quanto do papel da escola, à qual caberia corrigir a leitura e a escrita erradas. A Folha de S. Paulo, em 21 de maio de 2011, publicava a opinião de uma leitora que, indignada, defendia a leitura e a escrita corretas como fatores de "integração nacional" e estímulos para a "evolução das faculdades mentais e da aptidão verbal" (Folha de S. Paulo, 2011). Na mesma coluna e no mesmo dia, outro leitor orientava-se em sentido oposto, argumentando favoravelmente à diversidade de "práticas sociais formais e públicas da língua" e ao lugar da escola no reconhecimento dessa diversidade. Antes e depois dessa data, outras tantas matérias voltaram à questão, envoltas por disputas políticas, partidárias, conflitos sociais e olhares mais acadêmicos.

Neste artigo, a temática da linguagem aparece atrelada às discussões sobre escolarização, radiodifusão e humor nas décadas de 1930 e 1940. Embora as situações e os sujeitos sejam historicamente bem diferentes, aspectos tais como a "elevação" do nível cultural do povo; o combate às falas populares definidas como erradas; e a defesa da escola como instituição capaz de integrar a nação por meio do ensino de uma língua única, atenta às regras gramaticais, estiveram igualmente presentes num período em que amplos foram os debates sobre o papel da radiodifusão no País. Naquele tempo, tal como hoje, dois grupos podiam ser mais diretamente identificados: um defendia a função educativa do rádio, veículo que poderia vir a ser o professor onipresente de todos os brasileiros, inclusive dos analfabetos; outro, apostando no rádio como instrumento de diversão, adotava uma posição mais flexível e uma programação mais próxima do gosto popular. Em ambos vislumbram-se argumentos semelhantes àqueles que povoam as páginas dos jornais contemporâneos. 
Mais especificamente, analisam-se aqui repercussões satíricas dos processos de escolarização no Brasil, constantes em antigos programas humorísticos de rádio que, geralmente organizados pelo diálogo entre um professor e seus alunos, foram simultaneamente grandes sucessos em termos de audiência e alvos de uma crítica sistemática por parte daqueles que defendiam a radiodifusão como instrumento de divulgação da "verdadeira" cultura. Embora a relação entre rádio e educação não constitua um campo inédito no âmbito da história da educação brasileira, os trabaIhos a ela dedicados focam, de modo mais frequente, as propostas dos pioneiros do rádio no Brasil, iniciativas do Estado para a expansão e a normatização da radiodifusão ou programas mais claramente educativos. Por vezes vistos como "menores”, os humorísticos são antes lembrados que analisados, situação agravada pela dificuldade de acesso às fontes sonoras. Recuperando pequenos fragmentos desses programas e investigando sua repercussão em diferentes periódicos, este trabalho objetiva compreender as razões do sucesso desse gênero e, neste percurso, reconhecer as críticas que jocosamente veicularam aos processos de escolarização do social, explicitadas em conflitos entre sonoras tradições populares e saberes escolares.

\section{Educar ou divertir?}

As primeiras transmissões radiofônicas no Brasil foram feitas nos anos 1920, embaladas pelo ideal educativo de Roquette Pinto e de outros que sonhavam fazer do rádio o grande "professor" da nação. Essa vontade era manifestada tanto na programação da Rádio Sociedade do Rio de Janeiro, fundada em 1923, quanto nas revistas Radio e Electron, publicadas pelo grupo, que começaram a circular, respectivamente, em 1923 e 1926 (Duarte, 2008). Esses periódicos ofereciam aos leitores artigos que tratavam do papel social do rádio, aspectos técnicos ligados aos aparelhos e às antenas, grade de programação, reprodução de algumas transmissões e, por fim, material publicitário, a maior parte referente à comercialização de aparelhos.

Diante da raridade de registros sonoros daqueles primeiros tempos, essas revistas ajudam a compreender quais eram os objetivos dos pioneiros da radiodifusão no Brasil. Em relação à programação, além de música erudita, jornalismo e esportes, a grade estava repleta de cursos de história do Brasil, geografia, ortografia portuguesa, lições de inglês e francês, literatura, higiene, dicas para o lar; havia, ainda, a leitura de textos edificantes com vistas à formação moral das crianças. Nos editoriais, menções constantes a discursos de Roquette Pinto - quando da inauguração da Rádio Socie- 
dade e em outros momentos - procuravam reforçar esta nobre missão dos serviços de radiodifusão:

... Todos os lares espalhados pelo immenso território do Brasil receberão livremente o conforto moral da sciencia e da arte; a paz será realidade definitiva entre as nações. Tudo isso há de ser o milagre das ondas mysteriosas que transportam no espaço, silenciosamente, as harmonias (Roquette Pinto, 1924, p. 5)

A proposta da integração nacional via rádio e do progresso pela vulgarização da ciência e da arte estava presente em muitas manifestações de Roquette Pinto. Dois anos mais tarde, na primeira página de Electron, nova defesa aparece:

... Hão de trabalhar melhor e produzir mais, os nossos patrícios, saibam ler ou não, quando o rádio conseguir pousar, no seu vôo infinito, em todos os arraiaes. [...] Rádio é o jornal de quem não sabe ler; é o mestre de quem não pode ir à escola; é o divertimento gratuito do pobre; é o animador de novas esperanças; o consolador dos enfermos; o guia dos sãos, desde que 0 realizem com espírito altruísta e elevado. Viver no sertão não é mais morrer em vida (Roquette Pinto, 1926, p.1).

Nos anos 1930, porém, as intervenções do Estado sobre a radiodifusão, o fortalecimento da indústria do entretenimento e o crescimento das empresas de comunicação promoveram profundas alterações no setor; rapidamente, aspectos mais comerciais passaram a concorrer com a antiga proposta educativa. Em 1931, um decreto presidencial estabelecia o monopólio do Estado concernente à autorização para criação de novas emissoras e para concessão das frequências. No ano seguinte, outro decreto permitia às emissoras a veiculação de propaganda comercial, medida que ofereceu novas e ampliadas possibilidades de lucro (Calabre, 2009). Com a adoção de programação mais variada - incluindo música popular, rádio-teatro, rádio-novelas, programas de auditório e humorísticos -, cresceu significativamente o número de ouvintes e, consequentemente, o de anunciantes. Dez anos à frente do pioneirismo de Roquette Pinto, outro era o panorama da radiodifusão brasileira: além das rádios "sociedade" e "clube", entidades civis sem fins lucrativos, mantidas por meio da contribuição 
mensal de sócios que apostavam no rádio como um veículo ideal para a educação do povo, havia agora uma quantidade crescente de emissoras comerciais, gerenciadas empresarialmente, com provimentos advindos da propaganda.

Essa nova radiodifusão que emergiu nos anos 1930 apresentava um caráter mais profissional. Diferentemente das antigas programações, nas quais, muitas vezes, a linguagem era a mesma do escrito, com a leitura de trechos de jornais, livros didáticos e outros textos adequados à norma culta, as novas estações procuravam se aproximar mais da oralidade das ruas, visando ampliar o número de ouvintes. Diversificaram sua programação musical, incluindo ritmos então considerados menores - como o samba e o jazz -, e inauguraram programas de variedades que rapidamente conquistaram o gosto popular. Eram emissoras que funcionavam como empresas de comunicação, muitas agregando rádio, jornal e revistas. Se, a partir do início dos anos 1930, houve um aumento constante da ação do Estado no sentido de controlar a radiodifusão, impondo exigências técnicas que só uma orientação empresarial poderia suprir, por outro lado, essas mesmas exigências e a liberação para a propaganda permitiram um barateamento dos custos e criaram um público fiel, que se identificava mais com essa nova programação do que com a antiga defesa da difusão da ciência e da "verdadeira" cultura.

A ausência de consenso sobre esse novo panorama radiofônico, porém, continuou a suscitar polêmicas, e não poucas vozes se levantaram para defender a retomada dos ideais primeiros. Há vários indícios desta contenda nas páginas de Fon Fon, semanário ilustrado carioca publicado entre 1907 e 1958. Em geral, críticas ao caráter mercantil das emissoras e à programação podem ser encontradas em cartas de leitores e outros comentários da seção “PR1 Fon Fon”. Muitas incidem sobre a questão de linguagem. No exemplar de 16 de setembro de 1939, na Tribuna dos Radio-Ouvintes, lê-se o comentário de um paulista indignado diante da programação de emissoras do Estado e temeroso da influência do rádio sobre as crianças:

Aqui quase todas as emissoras bandeirantes possuem programas a cargo de 'speakers' caipiras. Tais programas, em que não se ouve uma anedota, uma conversa boa, nada de interessante, são horrivelmente insípidos, só com os seus anúncios e dedicatórias que não acabam mais em linguagem de Jeca Tatu. Sem falar no prejuízo que esses programas podem trazer as nossas crianças as quais, ouvindo diariamente essa linguagem roceira, podem viciar-se. (FON FON, 16 set. 1939, s/p). 
Não se tratava de uma voz isolada. Entre outubro de 1938 e fevereiro de 1940, Alziro Zarur publicou na revista o inquérito "O que é o rádio? Fator de educação ou de diversão?”. Segundo Zarur, a enquete privilegiava as “opiniões autorizadas”, entendidas como aquelas de intelectuais que pudessem contribuir para o aprimoramento da radiodifusão no Brasil (Fon Fon, 1 out. 1938, p. 33). Um dos entrevistados, Berilo Neves, jornalista e escritor, enfurecido diante do que considerava uma ameaça ao progresso do País e à gramática, registrou que o rádio deveria ser a "biblioteca volante do povo" e que os compositores populares, em direção inversa, "subiam o morro esquecendo de levar consigo qualquer compêndio de gramática", privilegiando ritmos ao invés da letra (Fon Fon, 3 dez. 1938, p. 36).

Foram 62 entrevistas, nas quais, em raras ocasiões, puderam ser lidas também as opiniões de alguns cantores e compositores que se colocaram abertamente na defesa do samba como gênero musical popular brasileiro, dos programas de humor, da leveza do riso e de um rádio abertamente comercial. Dos 62 entrevistados, 3, entre eles 0 próprio Roquette Pinto, posicionaram-se a favor de um rádio estritamente educativo; 9 defenderam o rádio apenas como diversão; e 50 disseram preferir um caminho capaz de harmonizar as duas tendências, sinalizando para as vantagens advindas nos novos tempos (Fon Fon, 20 jan. 1940, p. 30). Ao longo dos meses em que a enquete foi publicada, as palavras de Alziro Zarur, na abertura da seção, criticaram, particularmente, três aspectos: as letras das canções populares; os anúncios radiofônicos que, para sensibilizarem o ouvinte, se aproximavam das falas populares; e os programas de humor, nos quais, para ele, a língua portuguesa era seguidamente vilipendiada.

Essa era também a opinião de Martins Castelo, que, por várias vezes, escreveu sobre o rádio na revista Cultura Política, publicação mensal ligada ao Departamento de Imprensa e Propaganda, veiculada entre março de 1941 e outubro de 1945. A revista tinha por objetivo discutir grandes temas da cultura brasileira - literatura, música, artes plásticas; apresentava também personagens e fatos "relevantes" da história nacional, além de muitas páginas dedicadas à ação do Estado para promover a cultura. A radiodifusão foi tema frequente de suas páginas, com vários artigos de opinião assinados por Martins Castelo, nos quais se expressavam temores em relação à influência do rádio sobre a população:

0 rádio, entregue à exploração de empresas particulares, apresenta um grande inconveniente. 0 anunciante, pagando o tempo durante o qual o 
'seu programa' - 'sponsored program' - ocupa o microfone, é quem sustenta a radiodifusão. E, com o objetivo de garantir a eficácia da publicidade, procura 'agradar o ouvinte', que é provável freguês, esquecendo muitas vezes a função educativa do rádio. [...] 0 'broadcasting' passa, não raro, a servir unicamente aos interesses do anunciante. E, desviando-se para as competições e as rivalidades, foge ao seu papel educativo, até se transformar em um instrumento de indisciplina, prejudicial à plasmação de uma normatividade (Castelo, 1941, p. 283).

Em outro volume, um artigo de Álvaro Salgado (1941, p. 85-87) denunciava a péssima qualidade do português falado nas rádios e qualificava as sonoridades populares como "ímpetos bárbaros" e "ritmos selvagens". 0 combate a essa tendência, que ele identificava com as tradições africanas, passava necessariamente pela escola e pela ação civilizatória dos homens cultos. Era preciso que o rádio se alinhasse aos objetivos da educação escolar, ao invés de combatê-los, "elevando o nível artístico e intelectual das massas", "cegas" e "analfabetas":

0 samba, que traz em sua etimologia a marca do sensualismo, é feio, indecente, desarmônico e arritmo. Mas paciência: não repudiemos esse nosso irmão pelos defeitos que contém. Sejamos benévolos; lancemos mão da inteligência e da civilização. Tentemos, devagarzinho, torná-lo mais educado e social... Não toleramos os moleques peraltas, dados a traquinagem de toda espécie. Entretanto, não os eliminemos da sociedade. Pedimos escolas para eles. A marchinha, o samba, o maxixe, a embolada, o frevo, precisam unicamente de escola. [...] Precisamos combater o desprezo e a negligência no estudo do português, matéria esta que infelizmente reprova mais candidatos a concursos e mais sofre com a inclemência dos que têm a dita de se exprimir nesse rico idioma. A rádio, transmitindo a voz, tem enorme responsabilidade. [...] Não são, portanto, admissíveis os descuidos via oral levados diariamente aos lares brasileiros (Salgado, 1941, p. 85-87).

Um aspecto importante nesse tipo de opinião é a culpabilização frequente da publicidade pela perda da qualidade da radiodifusão no Brasil. As peças publicitárias 
são atacadas como as grandes vilãs no processo de afastamento do rádio em relação a sua nobre missão educativa. No centro dessa argumentação, a ideia de que a linguagem publicitária, visando o "freguês", se afasta dos cânones da língua em direção a uma oralidade popular, marcada por erros, pela gíria, pela informalidade. Esta ideia nos coloca no cerne das discussões sobre a linguagem e sobre os conflitos sociais estabelecidos entre os defensores da norma culta da língua e os praticantes de falas mais populares socialmente significativas, uma contenda entre língua e palavra.

Talvez não seja equivocado afirmar que, no rádio, como na escola, tradições e projetos sociais distintos estavam em conflito: de um lado, os defensores da língua como fator de "unidade espiritual" do povo; de outro, oralidades variadas marcadas por regionalismos, identidades e sociabilidades, entendidas como erro. A linguagem publicitária do rádio, nesse contexto, pode reforçar esse entendimento, uma vez que sua raiz não é a da tradição escrita, pois nutre-se exatamente da oralidade das ruas e toma como um de seus "modelos" a fala dos trabalhadores ambulantes (Silva, 1999).

A questão não passou despercebida para o escritor Mário de Andrade, que, em 03 de fevereiro de 1940, publicava, no Diário de Notícias, o artigo "A língua radiofônica”, posteriormente incluído em várias coletâneas (Andrade, 2005). Naquela ocasião, ele tratou das especificidades da linguagem, em geral, e da linguagem radiofônica, em particular, tomando como mote a criação, na Argentina, de uma Comissão de Estudo e Reorganização do Serviço de Correios e Telégrafos, responsável também pela normatização e pela fiscalização da radiodifusão naquele país. Tal comissão suspeitava da espontaneidade dos speakers e da profusão dos tangos como bons exemplos a serem difundidos pelo rádio e, com vistas ao melhor equacionamento do problema, decidiu organizar um inquérito a ser respondido por diferentes "instituições culturais" argentinas. 0 inquérito, segundo Mário de Andrade, era composto por quatro questões referentes à transmissão de "vícios de pronúncia", uso da linguagem familiar nas comédias radiofônicas e da regional no teatro rural e, por fim, disseminação de ritmos musicais populares (Andrade, 2005, p. 113). Como se vê, eram questões próximas àquelas que vinham ocupando a pena de escritores, jornalistas e outros intelectuais brasileiros.

Mário de Andrade aproveitou-se do inquérito para abordar o tema da linguagem e sintetizou seu argumento, ao escrever que uma coisa é a "linguagem de Cervantes"; outra é a "linguagem castelhano-argentina" viva, plena de identidades sociais. E continua: 
A língua, no seu sentido, digamos, abstrato, é uma propriedade de todo o grupo social que a emprega. Mas isto é uma mera abstração. Essa língua não existe. 0 tempo, os acidentes regionais, as profissões se encarregam de transformar essa língua abstrata numa quantidade de linguagens concretas diversas. Cada grupinho, regional ou profissional, se utiliza de uma delas. Deus me livre negar a existência de uma língua "culta". Mas esta é exclusiva apenas de um dos grupinhos do grande grupo social. Essa é a língua escrita, por excelência, tradicionalista por vício, conservadora por cacoete específico de cultismo. Ou de classe. Mas já está mais que observado que os mesmos indivíduos que escrevem nessa língua culta, muitas vezes se esquecem dela quando falam. Essa língua escrita não é a mesma que a linguagem da classe burguesa, que é falada e não tem pretensões aristocráticas de bem falar. E existem as linguagens dos sentimentos, que fazem um burguesinho ter com a mulher um linguajar amoroso muito especial, ou ter tal linguagem nos momentos de cólera que jamais, como no vocabulário e na sintaxe, ele empregaria na festa de aniversário da filhinha. E, finalmente, existem as linguagens profissionais, a linguagem do carreiro, do sapateiro, do advogado. Ora, existe a linguagem do rádio também. 0 simples problema de alcançar o maior número de pessoas, de lhes ser acessível e as convencer a todas, obriga o rádio a uma linguagem mista, complexa, de um sabor todo especial... (Andrade, 2005, p.115).

No texto de Mário de Andrade reaparece, simultaneamente às opiniões divulgadas em meios impressos de comunicação brasileiros, a oposição entre língua e linguagem, entre o escrito e o dito, entre a unicidade da norma culta, seletiva e excludente, e a multiplicidade de linguagens constituintes das relações sociais - de amor, de trabalho, de classe - que nos conferem a alteridade. Impossível não relacionar suas conclusões aos estudos de Bakthin (1986) que, em Marxismo e filosofia da linguagem, propõe que todos os enunciados são socialmente constituídos. 0 sentido da fala não está nem no indivíduo, nem na palavra, nem no ouvinte: reside exatamente na interação verbal realizada através das enunciações, processo batizado de "dialogismo" (Bakthin, 1986).

Dentre tantos, os programas de humor foram alvos preferenciais das críticas daqueles que temiam as consequências da popularização da programação das emisso- 
ras e que ouviam, com desconfiança, a emergência de linguagens populares e dissidentes na interação verbal promovida pelo rádio.

\section{Rádio, humor e escolarização}

A programação humorística das emissoras de rádio nos anos 1930 e 1940 era bastante variada, com episódios de sátira política, de costumes e de relações familiares. Havia, ainda, programas de humor centrados em temáticas escolares e/ou educativas, vários deles apresentando o espaço da sala de aula e seus sujeitos como eixo central, estruturados a partir de diálogos entre professora e alunos. Esse era 0 caso de Cenas escolares, criado por Renato Murce, um dos pioneiros dessa nova fase abertamente comercial da radiodifusão. Murce, que começou no rádio como cantor lírico, trocou esta atividade pela organização de programas e pela busca de estabelecimentos que os patrocinassem. Em muitas ocasiões, ia também diretamente aos microfones (Murce, 1976, p. 23). Foi em 1936, quando convidado a assumir a direção artística da PRE-3 (Rádio Transmissora Brasileira), que Cenas escolares foi ao ar pela primeira vez, junto com outros sucessos criados especialmente para a emissora. Os personagens principais eram Manduca, interpretado por Lauro Borges; a professora Dona Teteca, interpretada inicialmente por Vera Regina; Coronel Fagundes e Seu Ferramenta, interpretados por Castro Barbosa. Ao longo dos muitos anos em que esteve no ar, alternaram-se bastante os radioatores que participavam do casting do programa, mas a dupla Lauro Borges e Castro Barbosa foi constante (Perdigão, 2003, p. 15). 0 programa reproduzia uma sala de aula à qual atendiam diferentes alunos, em busca de algum conhecimento. No ano seguinte, Murce foi contratado pela Rádio Clube do Brasil, onde permaneceu até 1945. Foi nessa emissora que o nome Cenas escolares foi substituído por Piadas do Manduca, numa tentativa bem-sucedida de contornar a censura imposta pelo Departamento de Imprensa e Propaganda, criado em 1939, que, entre outras coisas, o acusara de ridicularizar a escola e a docência. Junto com o nome, alterou-se também o cenário: não mais a sala de aula de uma escola pública e, sim, reuniões semanais na casa de uma professora aposentada, em companhia de seu marido, amigos e ex-alunos. Alterações feitas, o DIP permitiu que o programa voltasse ao ar, situação que Murce recorda com grande ironia, desdenhando dos censores (Murce, 1976, p. 62).

Os episódios da década de 1930, infelizmente, são até o momento desconhecidos. Mas há alguns registros sonoros dos anos 1940, especialmente aqueles veiculados pela 
Rádio Nacional - emissora na qual Murce trabalhou a partir de 1945 -, que permitem pensar sobre as relações entre rádio, humor e processos de escolarização do social. Um deles foi ao ar em 08 de março de 1947. 0 casting era composto por Anamaria, Brandão Filho, Renato Murce, além de Castro Barbosa e Lauro Borges. A situação era a de um jantar na casa de Dona Teteca, a professora, por ocasião de seu aniversário, todo ele transformado em evento pedagógico, em situação de ensino. A mestra, diante do acontecimento social para o qual convidara seus ex-alunos, procurava ensinar boas maneiras à mesa, boas relações entre os convivas, enfim, comportamentos adequados, além de preocupar-se em corrigir os erros das falas de alguns convidados. Nos diálogos, diferentes lógicas socializadoras entram em conflito (Thin, 2006). Opõem-se as perspectivas de Manduca, o aluno, às de Dona Teteca e seu marido, o Dr. Manfredo Leão, inspetor de ensino, pois Manduca preocupa-se o tempo todo com a comida em si, enquanto os anfitriões se incumbem de pensar na etiqueta à mesa, na música, nas homenagens à aniversariante. A transcrição de alguns trechos do programa indica esses conflitos²:

Manduca: "Como é? Tem comida ou não tem comida nessa funerária?"

Dona Teteca: "O que é isso? Calma! Calma, Manduquinha."

Manduca: "Tô cum fome."

Dona Teteca: "Isso é muito feio. Você já é um homenzinho. Deve se portar como gente."

Manduca: "Que como gente, que nada! Eu não sou antropófero. Eu quero cume é boia."

Dona Teteca: "Antropófago, menino!"

Manduca fala errado e quebra a argumentação da professora, mudando de assunto repentinamente. Sua urgência é com a comida. Ao tratar do realismo grotesco na obra de Rabelais, Bakthin (1987) afirma que o comer estava diretamente ligado à festa popular e à ideia da abundância e do desfrute. Para as classes populares na Europa do século XVI, a comilança simbolizava também o oposto do traba-

2. É impossível reproduzir literalmente os risos, os sussurros, a simultaneidade das falas e os "erros" de português presentes nas linguagens dos alunos. A transcrição feita aqui procura, tanto quanto possível, aproximar-se daquilo que se ouve. Decidiu-se por não indicar os erros formais, a fim de não truncar a leitura. Conta-se, assim, com a perspicácia do leitor para captar os trocadilhos e chistes. tho e de sua dureza e atrelava-se a uma ordem dos “de baixo". Bakthin permite considerar a hipótese de que a vontade de comer de Manduca, tão constante, não represente apenas certo primitivismo, mas o confronto entre duas lógicas diferentes: a sua, de aluno; 
e a de Dona Teteca, mestra carinhosa e paciente, ligada ao universo do culto, educado e civilizado. Nos diálogos, a hierarquia entre mestre e aluno é sempre colocada em revista, uma vez que as respostas de Manduca parecem pouco importar-se com os corretivos da professora, situação que se repete na relação com outros alunos, como neste exemplo da fala de Seu Ferramenta, o aluno português, comerciante, identificado pelo sotaque:

Seu Ferramenta: “Calma, calma, pessoal! É preciso que esse bacalhau dançante que nós vamos oferecer a Dona Teteca saia na mais perfeita bacanal." Várias vozes: "Heim? 0 quê?"

Seu Ferramenta: "Eu quero aqui muita indisciplina e imoralidade."

Várias vozes: “Como? Heim?"

Dona Teteca: "Mas o que é isso? O senhor troca os termos todos, Seu Ferramenta!"

Seu Ferramenta: "Eu não troco coisa nenhuma porque eu não tenho troco."

Novamente, a contestação da hierarquia está presente na resposta jocosa do aluno e nas referências ao grotesco, na fala sobre o bacanal e sobre a imoralidade. Ainda segundo Bakthin (1987), a festa popular caracterizava-se pela inversão das relações hierárquicas, processo no qual o riso tinha um papel destacado, e pela consagração da igualdade. Ao contrário da festa oficial, marcada pela repetição e pela reiteração da ordem, a folia popular, mesmo que pelo escracho, era momento - fugidio - de um movimento em direção à mudança, ao novo e à igualdade. Compreender a oposição entre os bons modos que Dona Teteca almeja e a vontade de comida e diversão de seus alunos apenas como descaso em relação à figura docente pode, portanto, ser restritivo. Na irreverência do trato com a mestra, alunos talvez construam, no momento da festa, uma outra possibilidade que extrapola o tempo e o espaço específicos daquele evento.

0 programa também permite discutir as visões da docência e, numa perspectiva ampliada, da autoridade. Em várias situações, Dona Teteca, a aniversariante que deveria ser homenageada, transforma-se em alvo de chacota. Ao agradecer Seu Ferramenta pela doação de grande quantidade de legumes e ovos, obtém como resposta que a razão de tal generosidade era o fato de que as mercadorias estavam com a data de validade vencida; ao entusiasmar-se diante da possibilidade de ganhar um presente de seu aluno dileto, Manduca, decepciona-se com o fato de que ele the trouxe caquis, fruta não apreciada pela professora e, pior, que ele pede para comer; por fim, desencanta-se dian- 
te de uma bacalhoada que não tem bacalhau. No conjunto, as falas sinalizam para a docência como sacrifício e ironizam até mesmo as recompensas simbólicas pelo trabalho.

Apesar das dificuldades, das decepções e das respostas malcriadas, as falas de Dona Teteca ao longo do programa são marcadas pela paciência e pela correção constante de todos os erros - de linguagem e de conduta - de seus alunos. Assim, ao mesmo tempo que a autoridade docente é relativizada, outros sentidos são destacados: a professora é casada com um doutor que também pertence à carreira do magistério; ela deseja ter sempre toda a paciência; insiste nas correções, mesmo com pouco sucesso; não perde o controle; agradece pelo encontro; pincela o jantar com comentários sobre arte; tem uma palavra de carinho para cada um dos convivas - enfim, educa. Continua a dedicar-se ao ofício, mesmo depois de aposentada, fazendo de seu lar uma extensão da escola e tratando quase como filhos aqueles que um dia foram seus alunos.

Paula Perin Vicentini e Rosário Genta Lugli (2009) investigaram as imagens sociais da docência e salientaram sua multiplicidade, destacando a oposição entre a recompensa simbólica do ofício e as lutas salariais dos professores, imagens ambíguas que, simultaneamente, colocam a mestra num grau hierárquico superior, em função de suas virtudes intelectuais e de caráter, e a rebaixam, em função dos indícios da difícil situação econômica. Dona Teteca, neste quadro, aparece como visão caleidoscópica, posto estarem presentes tanto os elementos da compensação simbólica - a recordação pelo seu aniversário, sua dedicação aos alunos e ao magistério, sua competência profissional - quanto aqueles que indicam a penúria da vida material, especialmente pela bacalhoada sem bacalhau, pela festa sem muitos convidados e, por fim, pelo escárnio de que, vez por outra, ao longo do programa, sua figura é vítima. Ainda em relação às imagens da docência, reforça-se a noção de que o magistério se construiu como profissão feminina, enquanto a carreira tendia a ser masculina, hipótese aqui ressaltada pela presença de um marido que era inspetor de ensino (Demartine; Antunes, 1993).

Além das visões da docência, estão presentes também as representações discentes. Afinal, o programa traz um conjunto de alunos que, de alguma maneira, estão associados aos sujeitos que, em especial nas décadas de 1930 e 1940, se pretendia educar: Manduca é o típico malandro carioca, sempre disposto a driblar o trabalho duro e a subserviência; Seu Ferramenta, nome que por si já indica uma condição, é o comerciante português preso às origens, à língua, e de poucos recursos cognitivos; Coronel Fagundes está sempre defasado em relação aos demais alunos. Todos representam grupos sociais específicos que, na cena carioca das primeiras décadas 
do XX, eram vistos como ameaça, por negarem as regras do trabalho fabril e urbano, manterem tradições de além-mar, serem ignorantes.

No mesmo episódio do programa, ainda na situação de homenagem à professora, depois de seu marido ter-lhe dedicado uma canção ao piano, momento que Dona Teteca chamava de "nossa hora de artes", Seu Ferramenta anuncia que fará uma "paróquia" para a mestra, que imediatamente o corrige, afirmando tratar-se de uma "paródia". No ritmo fácil da marchinha carnavalesca, com forte sotaque lusitano, Seu Ferramenta entoa nova sátira à figura docente:

Nem tudo que reluz é ouro

Nem tudo que balança cai.

A Senhora Dona Teteca

Quantos anos a Senhora faz?

Me disseram que é só quarenta.

Mas eu acho que é muito mais.

Nem tudo que reluz é ouro

Nem tudo que balança cai.

A idade a gente conhece

Nas pelancas que tem no focinho

A Senhora pra mim é mais velha

Que o cantinho que eu tenho no Minho.

Nem tudo que reluz é ouro

Nem tudo que balança cai.

A Senhora Dona Teteca eu me lembro

Da senhora dizer que tem "ite"

Do tempo que eu a conheço

A Senhora o que tem é "longite".

Nem tudo que reluz é ouro

Nem tudo que balança cai.

0 Dr. Leão já me disse

E eu acho que é mesmo verdade

Que casou-se contigo porque

Ele gosta de antiguidade. 


\section{Considerações finais}

Programas como o Cenas escolares, depois Piadas do Manduca, talvez nos ajudem a captar um momento em que muito fortes eram as oposições entre normas da escola e costumes populares, conflito que se radicalizava à medida que se expandia o ensino primário. Nessa direção, eles podem ser tomados simultaneamente como indícios da forte presença da escola no cotidiano e como denúncia de algumas das razões de seu fracasso; sinalizam a alteridade, ao criarem personagens que resistem às regras do espaço escolar e que o tempo todo relativizam os saberes da escola.

Outra questão importante relaciona-se à linguagem socialmente construída como marca identitária. Nesse contexto, a própria linguagem pode ser pensada como "costume", numa noção thompsoniana que, distante do folclore, concebe o costume como prática e lugar de resistência, um esforço para que marcas ancestrais não sejam apagadas por ações de caráter homogeneizador. Estudando práticas costumeiras dos trabalhadores ingleses no século XVIII e em parte do XIX, Thompson (1998) captou um momento no qual fortes eram as pressões, "vindas de cima”, para que a cultura popular fosse transformada, pressões que tiveram na escola um de seus principais lócus de atuação. Naquelas circunstâncias de embate, recorrer às práticas costumeiras foi uma tática de enfrentamento das forças sociais emergentes, especialmente de novas formas de organização dos processos e das relações de trabalho, sob moldes que os trabalhadores percebiam como prejudiciais. Recorrer ao costume, então, não era um gesto conservador e, sim, rebelde, perante, por exemplo, a racionalização do trabalho e os modos de exploração da terra que surgiam com os cercamentos (Thompson, 1998).

Programas como estes que foram citados podem ser rastros de uma cultura tradicional popular e rebelde, em relação tanto à escola quanto aos princípios de hierarquia e autoridade que se estabeleciam dentro e fora dessa instituição, especialmente quando se consideram os pilares da formação do brasileiro, adotados pelas elites nos anos 1930 e 1940, a saber: educação, trabalho e saúde, tríade que envolvia o cultivo do corpo, dos comportamentos, do intelecto, da moral e dos sentimentos (Gomes, 2000). As linguagens dos personagens, tratadas todas como conjuntos de erros, constroem um sentimento de pertença que, no caso aqui específico, a escola muitas vezes acaba por marginalizar; conservá-las pode significar uma prática de resistência.

Inseridos numa condição social intermediária, os pioneiros da radiodifusão comercial identificaram na fala das ruas um caminho para o sucesso do rádio, incorporando- 
-a nos programas e nos anúncios de propaganda. Ao mesmo tempo, como homens de rádio que conheciam a trajetória do veículo e estavam ligados às empresas que reuniam jornais, revistas e emissoras, participavam provavelmente de um universo mais ilustrado e escolarizado. Os personagens que criaram ora se inclinavam para um grupo, ora para outro e, assim, levavam ao ar muitos dos conflitos sociais daquele tempo. As fontes sonoras, mesmo que em fragmentos, permitem, então, investigar algumas repercussões dos processos de escolarização do social no Brasil e captar tensões entre diferentes projetos de vida e sociedade. Nelas, os erros de linguagem talvez possam ser lidos como confrontos em múltiplas direções: entre a norma culta da língua e as tradições da oralidade, entre a escola e o aluno, entre a padronização e a diferença, entre estratégias dos vencedores e astúcias dos vencidos (De Certeau, 1996).

\section{Referências bibliográficas}

AGUIAR, C. A. et al. Por uma vida melhor. São Paulo: Global, 2009. 286p. (Coleção viver e aprender).

ANDRADE. M. A língua radiofônica. In: MEDITSCH, E. (Org.). Teorias do rádio. Florianópolis, SC: Insular, 2005. p. 113-117.

BAKHTIN, M. A cultura popular na idade média e no renascimento. São Paulo: Hucitec, 1987. 419p.

BAKHTIN, M. Marxismo e filosofia da linguagem. 3. ed. São Paulo: Hucitec, 1986. 196p.

CALABRE, L. Políticas culturais no Brasil. Rio de Janeiro: Editora FGV, 2009. 144p.

CAStelo, M. Rádio. Cultura Política - Revista Mensal de Estudos Brasileiros, Rio de Janeiro, ano 1, número 4, p. 283-285, jun. 1941. Disponível em: http://cpdoc.fgv.br. Acesso em: 06 set. 2011.

DE CERTEAU, M. A invenção do cotidiano. Petrópolis, RJ: Vozes, 1996. v. 1 (Artes de fazer) $351 \mathrm{p}$.

DEMARTINI, Z. B.; ANTUNES, F. F. Magistério primário: profissão feminina, carreira masculina. Cadernos de Pesquisa, São Paulo, número 86, p. 5-14, ago. 1993.

DUARTE, A. Roquette Pinto e a Rádio Sociedade do Rio de Janeiro: coletâneas de documentos. 2008. 202p. Dissertação (Mestrado Profissional em Bens Culturais e Projetos Sociais) - Fundação Getúlio Vargas, Rio de Janeiro. 
FOLHA DE S. PAULO. Painel do Leitor, 21 maio 2011. A3.

FON FON. Entrevista com Berilo Neves, 1 de out. 1938, p. 36.

FON FON. O que é o rádio? Fator de educação ou de diversão?. Tribuna dos Radio-Ouvintes, 16 set. 1939.

GOMES, A. C. Capanema, o ministro e seu ministério. Rio de Janeiro: Editora Fundação Getúlio Vargas, 2000. 272p.

MURCE, R. Bastidores do rádio. Rio de Janeiro: Imago, 1976. 165p.

PERDIGÃO, P. No ar, PRK-30. Rio de Janeiro: Casa da Palavra, 2003. 204p.

ROQUETTE PINTO, E. Alto falante. Electron, Rio de Janeiro, anno 1, n. 4, p. 1, mar. 1926. Disponivel em: 〈http://www.fiocruz.br〉. Acesso em: 06 set. 2011.

ROQUETTE PINTO, E. Discurso na seção inaugural da Rádio Sociedade. Rádio, Rio de Janeiro, anno 1, n. 19, p. 5, jul. 1924. Disponível em: 〈http://www.fiocruz.br〉. Acesso em: 06 set. 2011.

SALGADO, A. Radiodifusão, fator social. Cultura Política - Revista Mensal de Estudos Brasileiros, Rio de Janeiro, ano 1, n. 6, p. 79-93, ago. 1941. Disponível em: http:// cpdoc.fgv.br. Acesso em: 06 set. 2011.

SILVA, J. L. O. A. Rádio: publicidade mediatizada. 2. ed. São Paulo: AnnaBlume, 1999. $115 \mathrm{p}$.

THIN, D. Para uma análise das relações entre famílias populares e escola: confrontação entre lógicas socializadoras. Revista Brasileira de Educação, Rio de Janeiro, v. 11, n. 32, p. 211-225, maio/ago. 2006.

THOMPSON, E. P. Costumes em comum. São Paulo: Companhia das Letras, 1998. 493p.

VICENTINI, P. P.; LUGLI, R. G. História da profissão docente no Brasil. São Paulo: Cortez, 2009. 234p.

\section{Fonte Sonora}

RÁDIO NACIONAL. Piadas do Manduca. Rio de Janeiro, 08 mar. 1947. Rio de Janeiro: Acervo do Museu da Imagem e do Som; Collector's Studios Ltda, Serviço de Restauração de Acervo.

Recebido em 27 de setembro de 2011 e aprovado em 15 de maio de 2012. 
